\title{
Review
}

\section{Cancer-Selective Therapy of the Future}

\section{Apoptin and Its Mechanism of Action}

Subbareddy Maddika
Francisco J. Mendoza
Kristin Hauff
Christina R. Zamzow
Ted Paranjothy
Marek Los
1,3,*

'Manitobo Institute of Cell Biology; ConcerCare Manitobo; ${ }^{2}$ Department of Pharmacology and Therapeutics; ${ }^{3}$ Department of Biochemistry and Medical Genetics; University of Manitobo; Winnipeg, Canado

-Correspondence to: Marek Los; Manitoba Institute of Cell Biology; CancerCore Manitobo; 0N6010-675 McDermot Avenue; Winnipeg MB R3E OV9 Conada; Tel.: 204.787.2294; Fax: 204.787.2190; Email: Losmi@cc.umanitobo.co

Received 12/11/05; Accepted 12/12/05

Previously published online as a Cancer Biology \& Theropy E-publication: http: //www.londesbioscience. com/iournals/cbt/abstract.php?id $=2400$

\section{KEY WORDS}

Bcl-2, circovirus, cyclosome, Exportin, RXR, Ran

\section{ABBREVIATIONS}

APC Anaphase Promoting Complex, Cyclosome

ARM arginine rich motif

Kap karyopherins

NES nuclear export signal

NLS Nuclear Localization Signal

NPC nuclear pore complex

PML promyelocytic leukemia nuclear bodies

SNP Single Nucleotide Polymorphism

\section{ACKNOWLEDGEMENTS}

M.L. thankfully acknowledges the support by the CFI, Canada Research Chair program, PCRFC, MMSF, CCMF and HSC Foundation (Winnipeg) financed programs. The salary of S. Maddika has been supported by the MHRC and CCMF.

\section{ABSTRACT}

Classical chemotherapy, that specifically targets rapidly proliferating cells, has been in existence for over eighty years and has proven to be fully successful in only a limited number of cancers. Thus, this review focuses on a novel, emerging approach for cancer therapy that uses alternative, and more unique features of cancer cells. This new approach facilitates the selective targeting of cancer, while sparing normal, non-transformed cells. Examples of molecules that kill cancer cells selectively are: apoptin, E4orf4, viral protein R (VpR), and Brevinin-2R. Below we focus on apoptin, a product of the third open reading frame (VP3) of the chicken anemia virus. Besides discussing apoptin's mechanism of action, we also provide concise insight into the biology of a chicken anemia virus infection. Since apoptin's cancer-selective toxicity depends on its nuclear localization, we broadly discuss mechanism(s) involved in its nuclear retention (both nuclear import and export). We also discuss recent findings on apoptin's molecular mechanism of action, with a focus on the role of Nur77 in apoptin's nucleo-cytoplasmic signaling. Finally, we compare the current findings on apoptin to the mechanism of cancer selective toxicity of E4orf4. In the 'summary' -section, besides highlighting important issues related to cancerselective therapy, we also discuss concurrent approaches towards therapy personalization, particularly those related to the in vivo-, and real time cancer-therapy efficacy monitoring, using "lab-on-the-chip" and other emerging technologies.

\section{INTRODUCTION}

The attention given to chicken viruses has increased in recent years due to the avian flu outbreaks in Asia. Interestingly, a small protein called apoptin, that is a component of one of the viruses, Chicken Anemia Virus (CAV), has recently drawn a significant amount of attention due to its transformation-dependent retention in cell nuclei, and its selective toxicity towards transformed cells. Below, our aim is not only to portray apoptin, but, in a broader sense, to provide the basic information with respect to the biology of CAV infection. We also discuss the basic cellular processes and signaling pathways associated with apoptin's cancer selective toxicity.

\section{A SHORT DESCRIPTION OF CAV}

A member of the circovirus family, CAV is a very small, $(23-25 \mathrm{~nm})$ non-enveloped virus with a circular, single-stranded, DNA genome (containing the '- - strand of the DNA). ${ }^{1,2}$ CAV is an extremely resilient virus, capable of withstanding commercial disinfectants, a temperature of $131^{\circ} \mathrm{F}$ or $\mathrm{pH} 3$, for 30 minutes, making it difficult to eliminate the virus from a flock, once it became infected. ${ }^{3}$ Complete inactivation is observed only after high concentrations of iodine $(10 \%)$ are added for longer than two hours, or after 15 minutes of temperaturetreatment at $100^{\circ} \mathrm{C} .{ }^{4}$ Although first described in Japan, CAV, is found worldwide.

The CAV genome contains a 5' non-transcribed region displaying promoter activity. ${ }^{5}$ Within the genome, are three partially overlapping open reading frames, which collectively produce a single strand of unspliced RNA. ${ }^{5}$ Three viral proteins, termed VP1-3 are translated from CAV RNA and are found in all infected cells. VP1 $(50 \mathrm{kDa})$ is most likely the capsid protein, ${ }^{6}$ whereas VP3 $(-14 \mathrm{kDa})$, also know as apoptin, can be found within close proximity to nuclear chromatin. ${ }^{7}$ VP3 is necessary for CAV replication. ${ }^{7}$ Purified VP3 has been shown to induce apoptosis in infected thymic precursors, hemocytoblasts, chicken lymphoblastoid cell lines, malignant human lymphoblastoid cells, human osteosarcoma cells, ${ }^{7,8}$ and almost every other cell line tested. Apoptin is characterized in greater detail, in a following section. Less is known about VP2, however, its presence is necessary in 
conjunction with VP1 for the production of antibodies within the host. ${ }^{9}$

\section{BIOLOGY OF CAV INFECTION}

$\mathrm{CAV}$, also known as the chicken anemia agent or chicken infectious anemia virus, was first described in 1974 in Japan, as a disease that caused anemia, growth retardation, abnormal feathers, leg paralysis, intramuscular hemorrhages, and destruction of bone marrow and lymphatic tissue. ${ }^{10}$ Mortality rates can be as high as $60 \%$ but are generally around $1-20 \%$.

Transmission of CAV can occur vertically from hen to chick as well as horizontally through a flock. ${ }^{11,12}$ However, chicks born to infected hens may also possess maternal CAV antibodies, which would protect them from infections. ${ }^{13}$ Chickens of any age can develop an infection induced by CAV, but those under two weeks and lacking maternal antibodies are most susceptible. ${ }^{13}$

CAV infects dividing cells. Following 3-4 days after infection, $\mathrm{CAV}$ antigens can be found in hemocytoblasts of bone marrow, thereby leading to the induction of apoptosis (Fig. 1). ${ }^{13,14} \mathrm{~A}$ decrease in hemocytoblasts results in a depletion of erythrocytes, which is characteristic of anemia. Depletion of thrombocytes is the most likely factor to cause intramuscular hemorrhages. ${ }^{11}$ Only 16-18 days after infection, granulopoiesis and erythropoesis activities are reestablished in the bone marrow. ${ }^{15}$ In the thymus, CAV infects $\mathrm{T}$ cell progenitors whereas $\mathrm{B}$ cells are generally not vulnerable (Fig. 1). ${ }^{11,16}$ Also, macrophage activity has been shown to malfunction following CAV infection as characterized by diminished Fc receptor expression, phagocytosis, and microbicidal activity. ${ }^{17,18}$ The infection of hemocytoblasts and $\mathrm{T}$ cells leads to immunosuppression and a corresponding increase in viral, bacterial, or fungal infections. ${ }^{4}$

\section{APOPTIN}

Apoptin, a $\sim 15 \mathrm{kDa}$ proline-rich protein ${ }^{11}$ encoded by the VP3 gene of CAV, is believed to be the essential mediator of the generalized lymphoid atrophy and severe anemia that leads to the mortality of CAV-infected chickens. More interestingly, apoptin selectively induces apoptosis in transformed avian or mammalian cell lines, but not in primary, non-transformed cells. This has been proven, both by us and others, using a variety of cell types including 'human umbilical vein endothelial cells' (HUVEC), ${ }^{19}$ primary fibroblasts, primary lymphoid cells, keratinocytes, epidermal-, endothelial- and smooth-muscle cells. ${ }^{20}$ One report indicates some apoptosis induction in primary human embryonic lung fibroblasts. ${ }^{21}$ Thus, it cannot be excluded that embryonic cells or primary cells that are severely stressed (e.g., due to the lack of appropriate growth factors) may acquire partial sensitivity towards high doses of apoptin. Apoptin's cellular localization is crucial for its selective toxicity towards cancer cells. In primary cells, it remains in the cytoplasm, whereas in cancer cells it migrates into the nucleus and ultimately kills the cell by the activation of the mitochondrial death pathway, in a Nur77-dependent manner. ${ }^{22}$ The role of Nur77 in apoptin's toxicity is discussed in greater detail in the following chapters of this review. Phosphorylation of apoptin at the threonine (Thr)-108 residue, by an unknown kinase, ${ }^{23}$ is required for its nuclear retention, but not for its toxicity. ${ }^{21}$ The nuclear retention of apoptin, in tumor cells, appears to be governed by its inefficient nuclear export, caused by phosphorylation at Thr-108 (see the next two paragraphs for detailed discussion of nuclear import and export mechanisms). ${ }^{24}$

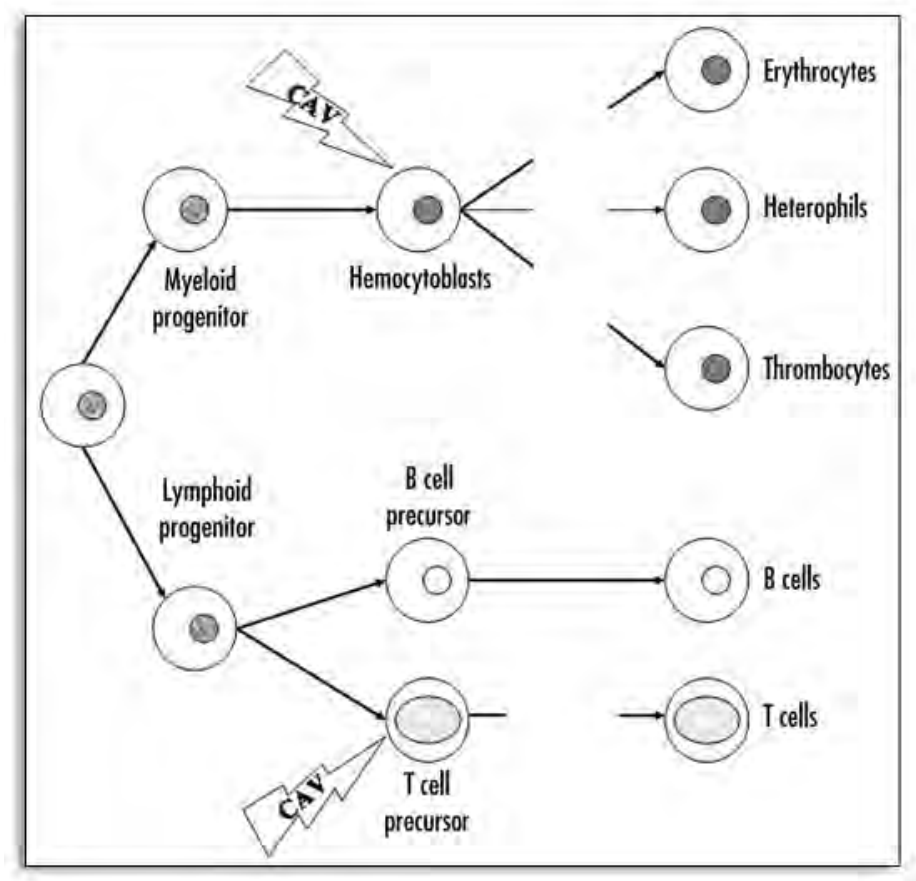

Figure 1. Effects of CAV on lymphatic cells and hemocytoblasts. CAV infects hemocytoblasts in bone marrow and T cell precursors. Infection of these cells leads to apoptosis and therefore a decrease in erythrocytes, heterophils thrombocytes and T cells. Adapted from Adair. ${ }^{11}$

Forced translocation of apoptin to the nucleus of primary, nontransformed cells does not render apoptin toxic for these cells. ${ }^{21,25}$ Thus, it is likely that additional modifications, and/or interaction partners specific for transformed cells, are necessary for apoptin to become toxic inside the targeted nucleus. Association of apoptin with the anaphase-promoting complex, and subsequent induction of $G_{2} / M$ arrest and apoptosis has recently been reported. ${ }^{26}$ Our unpublished data fully support the role of the anaphase-promoting complex in apoptin-triggered toxicity (Los M, Maddika S, unpublished). It is, however, unlikely that this is the sole mechanism responsible for apoptin's selective toxicity, since the anaphase-promoting complex is found also in normal cells.

\section{SIGNALING PATHWAYS THAT MAY CONTRIBUTE TO APOPTINS' CANCER-SELECTIVE TOXICITY}

It has been proposed that cell death caused by apoptin is independent of $\mathrm{p} 53$ and the Bcl-2 status of the cell. ${ }^{27}$ Data from our lab indirectly confirms the p53-independent action of apoptin, since apoptin was toxic for SV40 T-large-antigen transformed murine fibroblasts (T-antigen sequesters and inhibits p53). ${ }^{19,22}$ Contrary to previously published data, ${ }^{27}$ apoptin-induced cell death can be efficiently blocked by the anti-apoptotic molecule Bcl-2. ${ }^{19,22}$ Cytoplasmic colocalization of apoptin with Bcl-10 (which contains the caspase recruitment domain [CARD]) and FADD (containing the death domain $[\mathrm{DD}]$ and also the death effector domain [DED]) has been recently reported. ${ }^{21}$ Our own data, however, rules out the involvement of FADD as well as its interaction partners Fas and caspase- 8 in apoptin triggered cell death. ${ }^{22}$ Downstream caspases, including caspase-3, become activated upon apoptin expression in transformed cells. Cytochrome c release from mitochondria is also observed upon death induction by apoptin. ${ }^{19,22,28}$ 
It is, however, not well defined how apoptin that is present in the nuclei of transformed cells, activates the mitochondrial apoptotic pathway. Recent results published from our lab indicate the key role of Nur77 as an apoptin-triggered nucleo-cytoplasmic death messenger. Inhibition of Nur77 expression by siRNA significantly protects transformed cells from apoptin-induced death. ${ }^{22}$ We discuss the role of Nur77 and the possible signaling mechanisms in a paragraph placed towards the end of this review. Cellular localization of apoptin, and resulting site-specific interactions, appear to play a crucial role in its cancer-selective toxicity. ${ }^{29}$ Therefore, the following two paragraphs focus on the regulation of nuclear import and export mechanisms. They not only illustrate possible mechanism(s) implicated in apoptin's nuclear trafficking, but they are also intended to provide younger researchers with an appropriate foundation for further exploration in this area.

\section{NUCLEAR IMPORT MACHINERY}

As apoptin can only function to increase apoptosis when it is localized to the nucleus, ${ }^{25}$ the mechanism of its import, particularly how it can gain entry in transformed cells to a greater extent, is of great importance. The double membrane layer of the nuclear envelope is very effective at maintaining a spatial and temporal barrier between the genetic material and the cell's cytoplasmic components. This barrier functions to protect the cell's DNA from degradation and can act as an extra layer of regulation in transcription, as various factors necessary for transcription of certain genes are maintained outside the nuclear envelope until they are required. Macromolecules, such as apoptin, cannot penetrate the membrane and thus require active import into the nucleus. This active import requires a number of different components, and acts via the nuclear pore complex (NPC). Made up of a conglomerate of proteins, called nucleoporins, that span the nuclear envelope, the NPC forms a pore to allow large molecules to pass. In order to regulate the passage of these macromolecules, receptors, termed karyopherins (Kap) recognize nuclear localization signals (NLS) on the cargo to be transported, and mediate the transport through the NPC by an unknown mechanism (reviewed in ref. 30). The subsets responsible for nuclear import are known as the importins (IMP), of which there are eight known IMP $\alpha$ and $>20$ IMP $\beta$ forms in humans (reviewed in ref. 29). Although IMP $\beta$ can facilitate transport independently, IMP $\alpha$ often acts as an adaptor, and requires the IMP $\beta$ molecule to target the complex through the NPC (reviewed in ref. 31). Mutational analysis utilizing transformed and untransformed cells revealed a bipartite NLS in apoptin that interacts with IMP $\beta 1$ to facilitate nuclear import. ${ }^{24}$ The carboxyl terminal end of apoptin contains two clusters of basic amino acids separated by a 22 aa. spacer (Table 1).

There are many ways in which the cell can regulate the transport of macromolecules through the NPCs; the most basic of these is to limit transport machinery expression temporally and spatially. A NLS is only productive when it is recognized by its corresponding receptor, thus, production of certain components or cofactors by different cell types in different stages of development or under different (patho)physiologic conditions can regulate which cargoes are imported to the nucleus (reviewed in ref. 29). Another method of regulation can occur at the level of the macromolecule. Often there are sequences or sites just beyond the NLS on the molecule to be transported that can be modified by acetylation, phosphorylation or disulfide bond formation in order to alter the affinity of the NLS for its receptor (reviewed in Ref. 29). It was recently determined that nuclear accumulation of apoptin is enhanced by phosphorylation at Thr sequence within the spacer region of the NLS and just upstream of the nuclear export signal (NES), Thr-108. Rohn and colleagues were able to show an increase in nuclear accumulation and subsequent apoptosis in untransformed cells by introducing a glutamic acid mutation at position 108, and thereby mimicking constitutive phosphorylation. ${ }^{32}$ This phosphorylation of $\mathrm{Thr}^{108}$ is mediated by a kinase active in transformed cells and human clinical tumor samples, but not untransformed or normal cells. Interestingly, the results were confirmed in human clinical tumor samples, indicating the differential accumulation seen in transformed cells can be extrapolated to tumor cells as well. Recent work by Poon and colleagues, however, claims this phosphorylation may actually function to decrease nuclear export.

It is currently unclear how apoptin can differentially accumulate in transformed cells however, several different methods of nuclear import regulation are known to be employed by other macromolecules. A masking of the NLS can decrease the recognition of NLS sequences by their receptors and corresponding binding. This can be accomplished either by inducing a change within the protein (intramollecular masking), or by the addition of a supplemental molecule (intermolecular masking). Moreover, nuclear retention may be enhanced by the binding of components in the nucleus, which facilitate release from the nuclear import machinery. A Ras family guanine-nucleotide binding protein ( $\operatorname{Ran}$ ) in its active form, Ran-GTP, can associate with IMP $\beta 1$ to aid in the release of apoptin from the transport complex. ${ }^{33}$ To date, no study has reported that Ran participates in the regulation of apoptin's nuclear import. This process, if differentially regulated in normal and transformed cells, may contribute to cancer-selective apoptin's retention in the nucleus.

One theory explaining the differential import in transformed cells is that the accumulation is artificial, resulting from an increase in the efficiency of apoptin expression in transformed cells over primary cells, leading to a higher intracellular concentration of apoptin as compared to the untransformed cells. Reports of apoptin aggregation within cells, and even its requirement of aggregation to induce apoptosis lead to this concentration-dependent NLS hypothesis. ${ }^{34,35}$ However, one description of the apoptin aggregates revealed that, although they were present in normal cells, they were non-toxic due to the cell's ability to eventually eliminate the aggregates. ${ }^{36}$ Poon and colleagues revealed a 2 -fold increase in the ratio of nuclear to cytoplasmic localization of apoptin-GFP in transformed cells compared to their isogenic untransformed controls. ${ }^{24}$ Utilizing their ratiometric approach allowed the group to account for varying concentrations of apoptin between the cells. Although nuclear localization has been shown to be required for apoptin induced apoptosis, it is not sufficient, ${ }^{21}$ therefore, further research, considering functional outcomes of apoptin's nuclear import will be required to resolve this issue.

\section{NUCLEAR EXPORT OF APOPTIN}

The specificity of apoptin towards cancer cells is thought to derive from its ability to preferentially localize to the nuclei of transformed cells but not normal cells. ${ }^{37}$ Recent reports indicate that apoptin is in fact present in the nuclei of non-transformed cells, however this localization seems to be at lower levels compared to cancer cells. ${ }^{37}$ It is thought that apoptin is imported into the nucleus of both transformed and non-transformed cells. In normal cells, there is a mechanism that induces nuclear export and inhibits apoptosis whereas this process is inhibited (or much less efficient) in cancer 
Table 1. Nuclear import signal sequences.

\begin{tabular}{|c|c|c|c|}
\hline Sequence & Nuclear Import Receptor & Modifications & Reference \\
\hline FV-20aa spacer-MCSLCYMRTCGMF & Unknown & $\begin{array}{l}\text { Differential expression of NPC components has been } \\
\text { proposed }\end{array}$ & 115 \\
\hline GKKKKP & $\mid \mathrm{MP} \alpha / \beta 1$ & CK2 phosphorylation enhances, PKA inhibits import & 116 \\
\hline \multicolumn{4}{|l|}{ PKKKKP } \\
\hline KPPSKKR-22aa spacer-RPRTAKRRIKL & IMP $\beta$ & Phosphorylation in transformed cells may unmask NLS & 24,29 \\
\hline KRKK & $\mid M P \alpha 1 / \beta 1$ & Resembles monopartite SV40 NLS & 117 \\
\hline RRKRQR & $\mid M P \alpha / \beta 1$ & $\begin{array}{l}\text { PKA phosphorylation aids in NLS recognition and } \\
\text { releases from cytoplasmic retention signal }\end{array}$ & 118,119 \\
\hline RKSSSSRRKSQKSPRRR & Unknown & $\begin{array}{l}\text { Phosphorylation leads to intermolecular masking; } \\
\text { inhibits import }\end{array}$ & 120 \\
\hline RLKKLKCSKEKPKCAKCLKNNWECRYSPKTKR & IMPß1 & DNA facilitates IMP $\beta 1$ release & 121 \\
\hline RK-10aa spacer-RKTKKKIK & $|M P \alpha / \beta 1 ;| M P 7 / 8$ & Complex with HSP9O in absence of ligand masks NLS & \\
\hline RQARRNRRRRWRE & IMPß1 & mRNA aids in dissociation & 122 \\
\hline YGRKKRRQRRR & Positively charged domain & & \\
\hline RSSRGKRRRIE & $\mid \mathrm{MP} \alpha / \beta 1 ?$ & Phosphorylation inhibits import & 123 \\
\hline CNKRKYSLN & $\mid M P \alpha / \beta 1 ?$ & $\begin{array}{l}\text { Calcineurin dephosphorylates serine-rich region in response } \\
\text { to } \mathrm{Ca} 2+\text {, unmasking NLS }\end{array}$ & 124 \\
\hline GKRKKEEKRKR & $\mid \mathrm{MP} \alpha / \beta 1$ & $\begin{array}{l}\text { NLS masked by IKB protein, stimulus causes phosphorylation } \\
\text { and subsequent degradation }\end{array}$ & 125 \\
\hline RRKRR & Unknown & $\begin{array}{l}\text { MEIS } 1 \text { A binding induces a conformational change } \\
\text { unmasking NLS }\end{array}$ & 126 \\
\hline RIRYKKNISANKVTKNKSNSSPYLNKRKGKGPDS & IMPß3 (Pse 1) & Phosphorylation inhibits import & 127 \\
\hline RKRK & $\mid \mathrm{MP} \alpha / \beta 1 ?$ & NLS masked by MAPK $p 38 \alpha$ upon stimulation with TNF & 128 \\
\hline KRSAEGSNPPKPLKKLR & $\mathrm{IMP} \alpha / \beta$ & 129 & \\
\hline PKKKRKV & $\mid M P \alpha / \beta 1$ & Phosphorylation enhances import & $130-134$ \\
\hline KK-1 Oaaspacer-RKRGRPRK & $\mid M P \alpha / \beta 1$ & CDK phosphorylation masks NLS, inhibits import & 135 \\
\hline PLKKLKIDT & $\mid M P \alpha / \beta 1$ & phosphorylation reduces NPC binding & 136 \\
\hline RPRRKAK & IMPß 1 & $\begin{array}{l}\text { Acylation enhances IMP } \beta 1 \text { binding; DNA facilitates } \\
\text { IMP } 1 \text { release }\end{array}$ & 137,138 \\
\hline KRK-8aa spacer-KKAKV & $\mid M P \alpha / \beta 1$ & Dephosphorylation allows import & 139 \\
\hline
\end{tabular}

cells, thus causing apoptosis. Herein we give an overview of the nuclear export machinery and how it is regulated, with respect to apoptin.

\section{NUCLEAR EXPORT MACHINERY}

The nuclear envelope is a double membrane that obstructs the passage of proteins between the nucleus and the cytosol. Exchange of proteins between these compartments occurs across the NPC. ${ }^{38}$ Transport across the NPC is mediated by a family of soluble transport receptors named exportins. These are members of the IMP- $\beta$ family, whose most studied member is CRM1/Exportin-138,39 (Table 2). CRM1 binds to specific leucine rich sequences (LRS) on cargo proteins; these regions act as nuclear export signals (NES), in a Ranmodulated manner. ${ }^{38,40}$ Interactions of CRM1 with cargo proteins increase the affinity of CRM1 towards Ran-GTP, leading to the formation of a stable export complex. ${ }^{39}$ The NPC is a large complex formed by about 50-100 different proteins that are collectively referred to as nucleoporins. ${ }^{38,39}$ Transport through the NPC is facilitated by a number of low affinity hydrophobic interactions between CRM1 and nucleoporins containing phenylalanine-glycine repeats. Once the complex crosses the nuclear envelope, its disassembly must be induced to release the cargo into the cytosol ${ }^{38}$ (Table 2). Nucleoporin-214 (Nup214) is located at the nucleoplasmic end of the NPC and has high affinity to CRM1 in its Ran-GTP bound state; this interaction sequesters the export complex. ${ }^{38,39}$ Nup214 lies adjacent to the NPC filaments that contain RanBP2 and Ran $\mathrm{BP} 1$; these two proteins bind and change the conformation of Ran-GTP. This facilitates Ran-GAP hydrolysis of Ran-GTP into Ran-GDP, thus decreasing the stability of the export complex and discharging the cargo proteins into the cytosol (Table 2). ${ }^{39}$ Poon and colleagues reported that inhibition of CRM1 by leptomycin B increases nuclear localization of apoptin in normal cells but not in cancer cells. This indicates that in normal cells, the lower levels of nuclear apoptin are a result of export through the CRM1 pathway. ${ }^{24}$

\section{APOPTIN NUCLEAR RETENTION IN THE PRESENCE OF NES}

Tumor cells are capable of retaining apoptin in the nucleus even in the presence of a nuclear export signal. Masking the NES and thereby concealing it from exportin recognition can achieve nuclear localization. This can be the result of phosphorylation near the NES region, or a blockage due to protein-protein interactions. Furthermore, nuclear retention could be stabilized by the interaction 


\section{Table 2. Important proteins in the regulation of apoptin nuclear export; it includes a brief summary of their mode of action}

Protein
CRM1/exportin-1
Ran
Apoptin
Phenylalanine-Glycine repeat
nucleoporins
Nucleoporin-214 (Nup-214)
Ran binding protein 1 and 2
(RanBP1 and RanBP2)
Ran-GAP

Protein

CRM1/exportin-1

Ran

\begin{abstract}
Mode of Action
Binds to Nuclear export signals on cargo proteins

Ran-GTP: Has high affinity to CRM1 attached to cargo proteins. Forms the nuclear export complex. Ran-GDP: Has low affinity to CRM1.

Hydrolysis of Ran-GTP into Ran-GDP induces disassembly of nuclear export complex.
\end{abstract}

Nuclear Export Signal (NES): Recruits CRM1 in order to export apoptin. Sequence 97 VSKLKESLI. ${ }^{105}$ Threonine-108: Phosphorylation masks NES, allowing retention of apoptin in nucleus. Leucine Rich Sequence (LRS): Stabilizes nuclear retention by anchoring apoptin to promyelocytic leukemia nuclear bodies. Sequence ${ }^{33}$ IRIGIAGITITLSL. ${ }^{46}$

Forms part of nuclear pore complex (NPC); interacts with CRM1; important for transport across NPC.

Forms part of nuclear pore complex (NPC). It has strong affinity to CRM1 in Ran-GTP bound form. Sequesters export complex at cytoplasmic end of NPC. Allows interaction of Ran with Ran binding proteins.

Interact with Ran-GTP, changing its tri-dimensional structure and facilitating interaction with Ran-GAP

Hydrolyses Ran-GTP into Ran-GDP, it induces export complex disassembly. of apoptin with another protein that anchors it to the nucleus. ${ }^{29}$ Herein we give a synopsis of how these interactions could modulate the localization of apoptin.

Poon and colleagues reported the existence of a leucine rich region in apoptin between amino acids 97-105, having the sequence VSKLKESLI $^{24}$ (Table 2). Mutations at this site increased nuclear accumulation of apoptin in non-transformed cell lines but not in cancer cells. This suggests that this sequence is the NES responsible for nuclear export in normal cells. Phosphorylation near this sequence, at Thr-108, has been reported to be important for nuclear localization of apoptin in tumor cells. ${ }^{24,29}$ One possible explanation is that phosphorylation at this site masks the NES and favors nuclear accumulation. A point mutation replacing Thr-108 with a negatively charged glutamic acid, that mimics phosphorylation, also induces the accumulation of apoptin in the nuclei of non-transformed cells. ${ }^{29}$ Moreover, replacing Thr-108 with an alanine residue that is incapable of undergoing phosphorylation reduces nuclear accumulation of apoptin in transformed cells. Furthermore, inhibition of nuclear export by leptomycin B rescued nuclear localization to this mutant. ${ }^{24}$ These results indicate that phosphorylation of Thr-108 inhibits nuclear export in cancer cells; this nuclear export occurs through the mediation of CRM1. Phosphorylation of Thr-108 allegedly masks the NES and obstructs access to CRM1. However, this remains to be established through structural analyses.

Danen-Van Oorshot and colleagues reported the existence of another leucine-rich sequence between amino acids 33 and 46 of apoptin. ${ }^{25}$ This LRS with the sequence IRIGIAGITITLSL has been proposed to be a NES (Table 2). Association of apoptin with yet to be defined proteins in the nucleus is thought to block access of the nuclear export machinery to this LRS; this would result in nuclear retention and cell death. Concurrently, Poon and colleagues demonstrated that mutations within the initially reported leucine-rich region (aa. 97-105) reduced nuclear accumulation of apoptin in normal and transformed cell lines. ${ }^{24}$ This suggested that the LRS did not aid nuclear export, but, on the contrary, enhanced the presence of apoptin in the nucleus. Furthermore, they reported that apoptin localized to nuclear substructures that resembled promyelocytic leukemia nuclear (PML) bodies ${ }^{24}$ (also observed by Los and Schulze-Osthoff, unpublished). These are oligomers of PML protein present in cell nuclei; they are thought to serve as a depot for the storage of nuclear proteins such as CBP, p53, and HIPK2. ${ }^{41}$ Confocal microscopy revealed that apoptin effectively colocalizes with PML and HIPK; that this interaction was inhibited when the LRS was mutated. These results suggest that the leucine-rich sequence indeed contributes to nuclear localization by anchoring apoptin to PML bodies.

\section{THE ROLE OF Nur77 IN APOPTIN-INDUCED CELL DEATH}

The nuclear localization of apoptin is essential for its cancer selective toxicity. On the other hand apoptin-triggered cell death pathway(s) converge on the mitochondria, and they ultimately kill cancer cells by the apoptosome-dependent/intrinsic death pathway. ${ }^{19,22}$ Thus, a messenger of a pathway that would transmit a proapoptotic signal from nucleus to the cytoplasm has to be employed. Nur77 and p53 are two, well established molecules known to transmit death signals from the nucleus to the mitochondria. The role of $\mathrm{p} 53$ in transmitting apoptin's signal from the nucleus to mitochondria is ruled out as apoptin induced cell death is independent of the p53 status of the cell. ${ }^{8,22}$ Thus, the current focus is on the role of Nur77 in transmitting signals during apoptin-mediated activation of the mitochondrial death pathway.

Nur77 (NGFI-B, TR3. NR4A1 or NAK1), an orphan nuclear receptor, was first identified as an immediate-early gene induced by serum, NGF, or in response to seizures and mechanical lesions. ${ }^{42-44}$ It was further identified as a gene induced by $\mathrm{T}$ cell receptor signaling in T-cell hybridomas and thymocytes undergoing apoptosis. ${ }^{45} \mathrm{It}$ belongs to the NR4A family of orphan nuclear receptors, which also encompasses Nurr1 and Nor1. Nur77 protein has a typical steroid receptor structure composed of an $\mathrm{N}$-terminal transactivation domain, a central DNA binding domain containing two zinc fingers, and a C-terminus with homology to hormone-binding domains. ${ }^{46}$ Interestingly, the induction of Nur77 expression by different stimuli varies. Nur77 expression is transient during NGF, serum, or phorbol ester stimuli whereas $\mathrm{T}$-cell receptor activation leads to the stable expression of the gene. The kinetics of induction was shown to correlate with the action of Nur77. Stable expression of Nur77 often leads to apoptosis ${ }^{47}$ but the transient expression of Nur77 may not necessarily lead to apoptosis, but rather promotes cell cycle progression and acts as a survival factor. ${ }^{48-50}$ 
Nur77 was initially known for its role in cell proliferation and differentiation, but, later, was paradoxically shown to be a potent pro-apoptotic molecule. ${ }^{51,52}$ Overexpression of dominant negative Nur77 or antisense inhibition of Nur77 expression inhibits apoptosis where as constitutive expression of Nur77 induces rapid apoptosis. ${ }^{45,53-55}$ However, the fact that Nur77 and its family members, Nor-1 and Nurr1, are expressed as immediate-early genes in different cell types following various stimuli suggests that they play a role in a diverse set of biological functions. Indeed, Nurr1-deficient mice lack midbrain dopaminergic neurons and die soon after birth. ${ }^{56}$ Nur77 also acts as a transcription factor and regulates the expression of several genes like CD30, FasL, TRAIL, TGF- 33 , NDG1 and NDG2. ${ }^{57}$ Nur77 can bind to a consensus NBRE sequence (AAAGGTCA) as a monomer or to a palindromic DNA binding motif (NurRE, TGATATTTX6AAATGCCA) as a homodimer. ${ }^{58,59}$ Expression of Nur77, Nor-1, or Nurr1 alone is sufficient to activate NBRE or NurRE-directed transcriptional activities, suggesting that the Nur77 family members might be "constitutive" orphan steroid receptors that do not require ligands for activation. Nur77, apart from acting as a transcription factor as a monomer, also modulates the transcriptional activity of other steroid receptors. For instance, Nur77 heterodimerizes with Retinoid X Receptor (RXR) and regulates its transcriptional activity. ${ }^{60-62}$ Interestingly, Nur77 has also been reported to bind and alter the activity of COUP-TF, an orphan steroid receptor thought to negatively regulate the activation function of vitamin $\mathrm{D}$ receptor, retinoic acid receptor and RXR. ${ }^{63}$

The other very interesting feature of Nur77 is its ability to act differently based on its localization in the cells. Nur77 in the nucleus acts as a transcription factor and is known to regulate the expression of different genes either involved in proliferation or apoptosis. In the presence of certain stimuli such as TPA, NGF, 3-cl-AHPC and apoptin $22,48,53$ the localization of the protein switches to the mitochondria where it executes the mitochondrial apoptotic pathway by the release of cytochrome c. Two different mechanisms have been reported for the regulation of Nur77 translocation to the mitochondria. The first mechanism relies on the phosphorylation of Nur77 at different residues and the second mechanism involves the heterodimerization of Nur77 with RXR. The phosphorylation of Nur77, which results in its predominant localization in the cytoplasm, can be carried out by several kinases depending on the stimuli. These include members of the MAP kinase family and the protein kinase Akt. Akt phosphorylates Nur77 in its DNA binding domain at serine 351, resulting in the reduced Nur77 DNA binding activity and predominant localization in the cytoplasm. ${ }^{64,65}$ In PC12 rat pheochromocytoma cells, phosphorylation of Nur77 in its N-terminal region at serine 105 by members of the MAP kinase family (Trk/Ras/MAP kinase pathway dependent) regulates the ability of Nur77 to be exported to the cytoplasm in response to NGF. ${ }^{48}$ Nur77 contains three NESes located in the ligand binding domain, which when mutated causes Nur77 to remain in the nucleus despite the presence of NGF, and the intact serine phosphorylation site. This data suggests that NGF stimulation results in phosphorylation of Nur77, thus exposing the export signals within the C-terminal ligand binding domain and causing translocation of Nur77 to the cytoplasm. An alternate mechanism proposed recently for the regulation of Nur77 translocation to the mitochondria is dependent on the heterodimerization of Nur77 with RXR. During the process of apoptotic mitochondrial translocation, Nur77 forms a heterodimer with RXR at their DNA binding domains. The heterodimerization leads to the exposure of NESes on RXR (but not Nur77). ${ }^{66}$ In contrast, in the presence of RXR ligands, Nur77 and RXR heterodimerize at their ligand binding domains leading to the masking of RXR NESes. Thus, in the presence of RXR ligands, Nur77 translocation and apoptosis is inhibited despite the fact that it dimerizes with RXR indicating the crucial role of NESes during Nur77 export out of the nucleus to the cytosol. It has been further suggested that Nur77 may interact with $\mathrm{Bcl}-2$ at the mitochondria and convert it from an anti-apoptotic to a pro-apoptotic molecule. However this conversion theory may not be universally true for all the instances of Nur77 translocation and apoptosis, as we have shown that apoptin induced cell death which involves cytoplasmic Nur77 translocation, is effectively inhibited by the anti-apoptotic Bcl-2 family members. ${ }^{19,22}$ But on the other hand, we cannot completely rule out the possibility of Nur77 sequestering the anti-apoptotic Bcl-2 family members and thus shifting the balance among $\mathrm{Bcl}-2$ family members towards apoptosis rather than survival.

Recently, we have shown that apoptin mediated cell death is dependent on Nur77 expression in the cells, as the cells knocked down with Nur77 expression by specific siRNA are resistant to apoptin induced cell death. ${ }^{22}$ Furthermore we have shown that Nur77 transmits the apoptotic signal from nucleus to mitochondria by translocation upon apoptin treatment. The expression level of Nur77 varies in different cells. Nur77 is highly expressed in a broad range of cancer cells as compared to normal cells. ${ }^{63,67}$ Also, it has recently been shown that Nur77 is the one of the 17 signature genes associated with the metastasis of primary solid tumors. ${ }^{68}$ More evidence for Nur77 role in cancer came from the studies indicating that EWS, a member of Nur77 orphan receptor family is involved in the chromosomal translocation in human chondrosarcomas and the fusion protein is 250 fold more active if tested on TR3 responsive element mediated transcription. ${ }^{69,70}$ The difference in the expression level and the role of Nur77 (and Nur77 family members) in normal and cancer cells may contribute at least in part to the tumor specific toxicity of apoptin.

\section{E4orf4, -ANOTHER TUMOR-SELECTIVE KILLER}

As indicated in the beginning of this article, there are several other examples of molecules with (semi)selective toxicity towards cancer. Thus, below, we compare apoptin's known characteristics, with another viral protein with similar cancer-selective properties, E4orf4.

The E4orf4 (adenovirus type 5 E4 open reading frame 4) protein is a product of the E4 early transcription unit of adenovirus, which encodes seven open reading frames. ${ }^{71-73}$ E4orf4 is a small protein of 114 amino acids with no significant homology to any other known proteins. The protein has two distinct regions of amino acids in its structure: the proline rich region at the N-terminus (aa. 3-10, representing a typical SH3 consensus binding motif) and the second region containing mainly basic amino acids (aa. 66-75, representing a arginine rich motif (ARM) similar to HIV-1 Tat, Rev and HTLV-1 coded Rex protein). ${ }^{74-76}$ The functional significance of the proline rich region at the $\mathrm{N}$-terminus of the protein representing the $\mathrm{SH} 3$ binding motif is not known yet. The second motif of the protein, ARM, has recently been shown to be essential for the nuclear localization of the protein in the cells. The ARM directs E4orf4 to the nucleus and further promotes the nucleolar accumulation of the protein. ${ }^{74,77}$

Like apoptin, E4orf4, is selectively toxic towards cancer cells. E4orf4 specifically induces apoptosis in a wide range of cancer cells 
but not in normal primary cells. ${ }^{78-80}$ Similarly to apoptin, E4orf4's induced apoptosis is independent of p53 status of the cell. ${ }^{76}$ The role of caspases in E4orf4 cytoxicity is not clear. Caspase activation is shown in H1299 and 293T cells but not in other cell types. ${ }^{81}$ Furthermore, in contrast to apoptin's mechanism of action, ${ }^{22}$ E4orf4 mediated toxicity was shown to involve the activation of a death receptor dependent pathway as the cells expressing either dominant negative caspase- 8 mutant or dominant negative FADD mutant showed reduced cell death compared to wild type cells. ${ }^{81}$ However, it is not clear, how E4orf4 is able to activate the death receptor pathway. One possible mechanism might be that E4orf4 is activating the death receptors by controlling the transcription of death ligands or death receptors since E4orf4 has previously been shown to regulate E1A mediated transcription ${ }^{82,83}$ and also to control the splicing patterns of viral mRNAs. E4orf4 also activates the mitochondrial death pathway and the release of cytochrome $\mathrm{c}$, but the activation of caspase-9 has not been shown so far. Alternate, caspase-9 independent cell death pathways have been proposed. Thus, E4orf4 may induce its cytoxicity through the accumulation of ROS, downstream of caspase- 8 activation. ${ }^{81}$ E4orf4 requires at least $24-48$ hours to induce cell death, and likewise to apoptin, this process is inhibited by the anti-apoptotic Bcl-2 family members, Bcl-2 itself, and $\mathrm{Bcl}-\mathrm{X}_{\mathrm{L}} \cdot{ }^{84}$

E4orf4 mediated cytotoxicity towards transformed cells absolutely requires the interaction of E4orf4 with a phosphatase, PP2A. Accordingly, mutants lacking the interaction sites with PP2A are unable to induce apoptosis in these cells. ${ }^{76,80}$ Also, the transfection of cells with a PP2A antisense construct prevented E4orf4 induced cell death, thereby confirming the absolute requirement of PP2A during the cytotoxic effect of E4orf4. PP2A, a serine/threonine phosphatase, is a holoenzyme made of 3 subunits ( $\mathrm{A}, \mathrm{B}$ and $\mathrm{C}$ ) with different isoforms for each subunit. ${ }^{85}$ E4orf4 binds mainly to the $\mathrm{B} \alpha$ subunit of PP2A, but its interaction with other PP2A subunits has also been shown. However, the specific interaction of E4orf4 with $\mathrm{B}$ subunit of $\mathrm{PP} 2 \mathrm{~A}$, and not with other subunits, is essential for the induction of cell death. ${ }^{86}$ The downstream effector substrates of the E4orf4-PP2A complex are not known yet. It has been shown that E4orf4 leads to the reduced phosphorylation of different proteins either involved in transcription, or splicing. ${ }^{83,87-89}$ The E4orf4PP2a complex leads to hypophosphorylation of transcription factors c-Fos, E4F, and regulates their transcriptional activity, however, the kinases targeted by the E4orf4-PP2A complex in this process is not known. The complex of E4orf4 also leads to reduced phosphorylation of serine/arginine-rich (SR) proteins, which inhibits IIIA premRNA splicing. Thus, by dephosphorylating inhibitory SR proteins, E4orf4 activates the process of mRNA splicing. ${ }^{90,91}$ It is not currently known whether these molecules are the direct targets of the E4orf4-PP2A complex and/or whether these molecules play a role in E4orf4 mediated cell death.

Similarly to apoptin, E4orf4 is mainly localized in the nucleus of transformed cells, which is mediated by an arginine rich motif. But, the localization of the protein in normal cells has not yet been studied. It would be interesting to note if there is any difference in the localization of the protein between normal and cancer cells, as this may give some clues about the cancer specific toxicity of E4orf4. Nuclear E4orf4 is shown to induce irreversible growth arrest in the yeast strain, Saccharomyces cerevisiae, by physically interacting with the Anaphase Promoting Complex/cyclosome (APC). ${ }^{92-94}$ APC is an ubiquitination complex in the nucleus of the cell, and is required for the metaphase to anaphase transition during the cell cycle. Also like apoptin, the interaction between E4orf4 and the APC in the nucleus of mammalian transformed cells is shown to induce $\mathrm{G}_{2} / \mathrm{M}$ cell cycle arrest. Although it is reported that the E4orf4 interaction with the $\mathrm{APC} / \mathrm{C}$ subunit recruits higher levels of PP2A to the complex, the complete mechanism underlying the APC inhibition by E4orf4 is not yet clear. It is also shown that CDK1 (Cyclin Dependent Kinase 1, a component of Mitosis Promoting Factor) activity is elevated in E4orf4 over expressed cells, which correlates with APC inhibition. ${ }^{93}$

Though E4orf4 is seen in the nucleus of transformed cells, the protein is also found within cytoplasmic membranes. Interestingly, cytoplasmic E4orf4 is also active in inducing cell death, but with a distinct mechanism, in which it interacts with the src family of kinases and thus deregulates the survival signals mediated by these kinases. ${ }^{95,96}$ Unlike this, is the case with apoptin, where the nucleocytoplasmic shuttling of the protein is not affected by leptomycin B, an inhibitor of the CRM1 mediated nuclear export pathway. ${ }^{97,98}$ E4orf4 gets phosphorylated at tyrosine residues Y26, Y42 and Y59 by src kinases, and this phosphorylation, and the interaction with the src kinases inhibits the nuclear import of the protein. The tyrosine phosphorylation of E4orf4 is correlated with the cell death induced by cytoplasmic E4orf4, as the mutation of these residues impairs the killing activity of E4orf4. It is also shown that E4orf4's ARM interacts with the kinase domain of the src kinases and regulates tyrosine phosphorylation of some of the downstream targets like FAK, Paxillin (higher levels of phosphorylation) and cortactin (reduced tyrosine phosphorylation). ${ }^{96,99}$ The downstream effects of the regulation of this phosphorylation of src substrates, are the deregulated assembly of focal adhesions accompanied by changes in the actin cytoskeleton, membrane blebbing, and eventually the loss of survival signals. However, it is still not known how E4orf4 modulates the activity of the src family kinases. E4orf4 is also shown to activate $\mathrm{p} 70^{\mathrm{s} 6 \mathrm{k}}$ in a mTOR dependent pathway but independent of Protein Kinase B activation. ${ }^{100,101}$ The activation of $\mathrm{p} 70^{\mathrm{s} 6 \mathrm{k}}$ and mTOR by E4orf4 even in the absence of nutrient/growth factor signals plays a role in promoting adenoviral replication, but it is not revealed yet that this activation is required for the induction of cell death by E4orf4. Nonetheless, E4orf4 has two distinct pathways of inducing apoptosis either residing in the nucleus or at the cytoplasmic membranes and further work has to be done in deciphering the mechanism of tumor specific toxicity. Like apoptin, E4orf4 possesses great potential in becoming a lead molecule for the development of future anticancer therapies due to its selective toxicity towards transformed cells, and its p53 independent, pro-apoptosis.

\section{FUTURE DIRECTIONS OF CANCER-SELECTIVE THERAPIES}

Despite over ten years since apoptin's cancer-selective toxicity was discovered, several aspects of apoptin's biology are still controversial. For example, apoptin's toxicity has initially been reported to be caspase-independent, whereas scholars now agree that caspases participate in the execution of apoptin-triggered cell death. Another canon is the supposed sensitizing effect of Bcl-2 for apoptin's toxicity, which has recently been challenged by two labs. ${ }^{19,22}$ Even apoptin's cancer selective toxicity may not be a canon, as some authors have shown that primary embryonal cells may also be killed by higher doses of apoptin. ${ }^{21}$ Certainly, all scholars, so far, agree that apoptin requires to enter the nucleus in order to become toxic. Thus, the regulation of apoptin's nuclear retention is in the center of researchers' attention. It appears to be a multifaceted process. It involves nuclear import mediated through the two NLS in its sequence. The decision whether apoptin stays in the nucleus or is exported depends on the 
activity of a kinase yet to be identified. In transformed cells, this kinase is active and can inhibit apoptin's nuclear export by phosphorylating Thr-108. This phosphorylation is thought to inhibit the interaction of CRM1 with the NES and repress nuclear export. Phosphorylation is suppressed in normal cells, in which apoptin maintains an exposed NES that allows it to be shuttled out of the nucleus. There exists a second leucine rich region that seems to stabilize nuclear localization by anchoring apoptin with PML bodies in the nucleus.

It is clear that much remains to be understood regarding the mechanism of apoptin nuclear accumulation and subsequent apoptosis. Much has been learned from apoptin's cancer-selective toxicity. Unlike "standard" cancer therapies, apoptin appears to become "activated" by the very pathways that normally allow cancer cells to survive and proliferate. Our current understanding is that apoptin is able to "hijack" cell survival pathways and redirect them towards the activation of apoptotic pathways. While the general concept seems to be supported by experimental results, the exact mechanisms of apoptin's cancer selective toxicity still await elucidation. Several pieces of the puzzle however emerge: (1) apoptin is able to directly interact with DNA, thus it may impair a normally very active metabolism in cancer cells. (2) Increased expression of Nur77 has been observed in a broad range of cancer cells as compared to normal cells. ${ }^{63,67}$ (3) Apoptin interferes with the APC, thus it selectively targets proliferating cells. (4) Higher overall kinase activity in transformed cells may contribute to selective nuclear retention of apoptin in cancer cells. The list is certainly not complete, and it will be appended as we learn more about apoptin's mechanism of action. Nevertheless, it is most likely the combination of several qualities typical for cancer cells, that apoptin targets. This combination of attributes, specific for transformed cells, is what makes apoptin a highly cancer-selective killer.

This review focuses on molecules that selectively target cancer cells, however, cancer treatment could also be significantly improved if more personalized (adapted to the individual patient's (patho) physiology) therapy could be offered. Genome-wide mapping of Single Nucleotide Polymorphisms (SNPs), and thus the mining of information about the activity of enzymes that metabolize anticancer drugs, as well as molecules responsible for drug resistance is certainly one of the approaches that we will encounter in the clinic in the (not so distant) future. ${ }^{102}$ Detection of specific mutations within apoptotic pathways, would allow for the selection of appropriate anticancer drugs that can circumvent these problems. ${ }^{103}$ Yet, besides straightforward genomic approaches, other ways to combat some types of cancer and to individualize therapy should also be taken into account. (1) Since our immune system can recognize and remove "changed proteins", immunostimulation is becoming a promising, individualized and selective approach towards curing cancer and other diseases. ${ }^{104-108}$ (2) Every human being is genetically unique and this individuality plays a role in how well an individual responds to a particular drug. A drug administered to one patient may show no improvement, in comparison to another patient for whom the same drug has completely cured them. Thus, precise, in vivo monitoring of cancer therapy would allow drug dose individualization and quick identification of emerging resistance towards an administered drug. ${ }^{109,110}$ (3) Accumulating knowledge about interaction motifs as well as peptide sequences with very defined, pharmacologically-relevant features, makes it easier to develop new customized drug formulations that would allow either selective targeting of certain organs, or even certain organelles within a single cell. ${ }^{11-113}$
These, and other advances that are emerging in the rapidly changing medical environment, will most likely contribute in the near future to the more effective control of (or at least some types of) cancer.

\section{References}

1. Gelderblom H, Kling S, Lurz R, Tischer I, von Bulow V. Morphological characterization of chicken anaemia agent (CAA). Arch Virol 1989; 109:115-20.

2. Noteborn MH, de Boer GF, van Roozelaar DJ, Karreman C, Kranenburg O, Vos JG, Jeurissen SH, Hoeben RC, Zantema A, Koch G, et al. Characterization of cloned chicken anemia virus DNA that contains all elements for the infectious replication cycle. J Virol $1991 ; 65: 3131-9$.

3. Urlings HA, de Boer GF, van Roozelaar DJ, Koch G. Inactivation of chicken anaemia virus in chickens by heating and fermentation. Vet Q 1993; 15:85-8.

4. Goryo M, Shibata Y, Suwa T, Umemura T, Itakura C. Outbreak of anemia associated with chicken anemia agent in young chicks. Nippon Juigaku Zasshi 1987; 49:867-73.

5. Phenix KV, Meehan BM, Todd D, McNulty MS. Transcriptional analysis and genome expression of chicken anaemia virus. J Gen Virol 1994; 75:905-9.

6. Todd D, Creelan JL, Mackie DP, Rixon F, McNulty MS. Purification and biochemical characterization of chicken anaemia agent. J Gen Virol 1990; 71:819-23.

7. Noteborn MH, Todd D, Verschueren CA, de Gauw HW, Curran WL, Veldkamp S, Douglas AJ, McNulty MS, van der EA, Koch G. A single chicken anemia virus protein induces apoptosis. J Virol 1994; 68:346-51.

8. Zhuang SM, Shvarts A, van Ormondt H, Jochemsen AG, van der Eb AJ, Noteborn MH. Apoptin, a protein derived from chicken anemia virus, induces p53-independent apoptosis in human osteosarcoma cells. Cancer Res 1995; 55:486-9.

9. Noteborn MH, Verschueren CA, Koch G, Van der Eb AJ. Simultaneous expression of recombinant baculovirus-encoded chicken anaemia virus (CAV) proteins VP1 and VP2 is required for formation of the CAV-specific neutralizing epitope. J Gen Virol 1998; 79:3073-7.

10. Yuasa N, Yoshida I, Taniguchi T. Isolation of a reticuloendotheliosis virus from chickens inoculated with Marek's disease vaccine. Natl Inst Anim Health Q (Tokyo) 1976; 16:141-51.

11. Adair BM. Immunopathogenesis of chicken anemia virus infection. Dev Comp Immunol 2000; 24:247-55.

12. Hoop RK. Transmission of chicken anaemia virus with semen. Vet Rec 1993; 133:551-2.

13. Miller MM, Schat KA. Chicken infectious anemia virus: An example of the ultimate host-parasite relationship. Avian Dis 2004; 48:734-45.

14. Taniguchi $T$, Yuasa N, Maeda M, Horiuchi T. Chronological observations on hemato-pathological changes in chicks inoculated with chicken anemia agent. Natl Inst Anim Health Q (Tokyo) 1983; 23:1-12.

15. Smyth JA, Moffett DA, McNulty MS, Todd D, Mackie DP. A sequential histopathologic and immunocytochemical study of chicken anemia virus infection at one day of age. Avian Dis 1993 ; 37:324-38.

16. Adair BM, McNeilly F, McConnell CD, McNulty MS. Characterization of surface markers present on cells infected by chicken anemia virus in experimentally infected chickens. Avian Dis 1993; 37:943-50.

17. McConnell CD, Adair BM, McNulty MS. Effects of chicken anemia virus on cell-mediated immune function in chickens exposed to the virus by a natural route. Avian Dis 1993; 37:366-74.

18. McConnell CD, Adair BM, McNulty MS. Effects of chicken anemia virus on macrophage function in chickens. Avian Dis 1993; 37:358-65.

19. Burek M, Maddika S, Burek CJ, Daniel PT, Schulze-Osthoff K, Los M. Apoptin-induced cell death is modulated by Bcl-2 family members and is Apaf-1 dependent. Oncogene 2006; in press, doi: 10.1038/sj.onc. 1209258.

20. Danen-Van Oorschot AA, Fischer DF, Grimbergen JM, Klein B, Zhuang S, Falkenburg JH, Backendorf C, Quax PH, Van der Eb AJ, Noteborn MH. Apoptin induces apoptosis in human transformed and malignant cells but not in normal cells. Proc Natl Acad Sci USA 1997; 94:5843-7.

21. Guelen L, Paterson H, Gaken J, Meyers M, Farzaneh F, Tavassoli M. TAT-apoptin is efficiently delivered and induces apoptosis in cancer cells. Oncogene 2004; 23:1153-65.

22. Maddika S, Booy EP, Johar D, Gibson SB, Ghavami S, Los M. Cancer-specific toxicity of apoptin is independent of death receptors but involves the loss of mitochondrial membrane potential and the release of mitochondrial cell death mediators by a Nur77-dependent pathway. J Cell Sci 2005; 118:4485-93.

23. Rohn JL, Zhang YH, Aalbers RIJM, Otto N, den Hertog J, Henriquez NV, van de Velde CJH, Kuppen PJK, Mumberg D, Donner P, Noteborn MHM. A Tumor-specific kinase activity regulates the viral death protein apoptin. J Biol Chem 2002; 277:50820-7.

24. Poon IK, Oro C, Dias MM, Zhang J, Jans DA. Apoptin nuclear accumulation is modulated by a CRM1-recognized nuclear export signal that is active in normal but not in tumor cells. Cancer Res 2005; 65:7059-64.

25. Danen-van Oorschot AAAM, Zhang YH, Leliveld SR, Rohn JL, Seelen MCMJ, Bolk MW, van Zon A, Erkeland SJ, Abrahams JP, Mumberg D, Noteborn MHM. Importance of nuclear localization of apoptin for tumor-specific induction of apoptosis. J Biol Chem 2003; 278:27729-36.

26. Teodoro JG, Heilman DW, Parker AE, Green MR. The viral protein Apoptin associates with the anaphase-promoting complex to induce $\mathrm{G}_{2} / \mathrm{M}$ arrest and apoptosis in the absence of p53. Genes Dev 2004; 18:1952-7.

27. Danen-Van Oorschot AA, van der Eb AJ, Noteborn MH. BCL-2 stimulates Apoptin-induced apoptosis. Adv Exp Med Biol 1999; 457:245-9. 
28. Oro C, Jans DA. The tumour specific pro-apoptotic factor apoptin $(V p 3)$ from chicken anaemia virus. Curr Drug Targets 2004; 5:179-90.

29. Poon IK, Jans DA. Regulation of nuclear transport: Central role in development and transformation? Traffic 2005; 6:173-86.

30. Paschal BM. Translocation through the nuclear pore complex. Trends Biochem Sci 2002; 27:593-6.

31. Kau TR, Way JC, Silver PA. Nuclear transport and cancer: From mechanism to intervention. Nat Rev Cancer 2004; 4:106-17.

32. Rohn JL, Zhang YH, Aalbers RI, Otto N, Den Hertog J, Henriquez NV, Van De Velde CJ, Kuppen PJ, Mumberg D, Donner P, Noteborn MH. A tumor-specific kinase activity regulates the viral death protein Apoptin. J Biol Chem 2002; 277:50820-7.

33. Jans DA, Xiao CY, Lam MH. Nuclear targeting signal recognition: A key control point in nuclear transport? BioEssays 2000; 22:532-44.

34. Leliveld SR, Noteborn MH, Abrahams JP. Prevalent conformations and subunit exchange in the biologically active apoptin protein multimer. Eur J Biochem 2003; 270:3619-27.

35. Leliveld SR, Zhang YH, Rohn JL, Noteborn MH, Abrahams JP. Apoptin induces tumor-specific apoptosis as a globular multimer. J Biol Chem 2003; 278:9042-51.

36. Zhang YH, Leliveld SR, Kooistra K, Molenaar C, Rohn JL, Tanke HJ, Abrahams JP, Noteborn MH. Recombinant apoptin multimers kill tumor cells but are nontoxic and epitope-shielded in a normal-cell-specific fashion. Exp Cell Res 2003; 289:36-46.

37. Poon IK, Oro C, Dias MM, Zhang JP, Jans DA. A tumor cell-specific nuclear targeting signal within chicken anemia virus VP3/apoptin. J Virol 2005; 79:1339-41.

38. Kutay U, Guttinger S. Leucine-rich nuclear-export signals: Born to be weak. Trends Cell Biol 2005; 15:121-4.

39. Gorlich D, Kutay U. Transport between the cell nucleus and the cytoplasm. Annu Rev Cell Dev Biol 1999; 15:607-60.

40. Yoneda Y, Hieda M, Nagoshi E, Miyamoto Y. Nucleocytoplasmic protein transport and recycling of Ran. Cell Struct Funct 1999; 24:425-33.

41. Dellaire G, Bazett-Jones DP. PML nuclear bodies: Dynamic sensors of DNA damage and cellular stress. Bioessays 2004; 26:963-77.

42. Hazel TG, Nathans D, Lau LF. A gene inducible by serum growth factors encodes a member of the steroid and thyroid hormone receptor superfamily. Proc Natl Acad Sci USA $1988 ; 85: 8444-8$.

43. Milbrandt J. Nerve growth factor induces a gene homologous to the glucocorticoid receptor gene. Neuron 1988; 1:183-8.

44. Watson MA, Milbrandt J. The NGFI-B gene, a transcriptionally inducible member of the steroid receptor gene superfamily: Genomic structure and expression in rat brain after seizure induction. Mol Cell Biol 1989; 9:4213-9.

45. Woronicz JD, Calnan B, Ngo V, Winoto A. Requirement for the orphan steroid receptor Nur77 in apoptosis of T-cell hybridomas. Nature 1994; 367:277-81.

46. Carson-Jurica MA, Schrader WT, O'Malley BW. Steroid receptor family: Structure and functions. Endocr Rev 1990; 11:201-20.

47. Woronicz JD, Lina A, Calnan BJ, Szychowski S, Cheng L, Winoto A. Regulation of the Nur77 orphan steroid receptor in activation-induced apoptosis. Mol Cell Biol 1995; 15:6364-76.

48. Katagiri Y, Takeda K, Yu ZX, Ferrans VJ, Ozato K, Guroff G. Modulation of retinoid signalling through NGF-induced nuclear export of NGFI-B. Nat Cell Biol 2000; 2:435-40.

49. Kolluri SK, Bruey-Sedano N, Cao X, Lin B, Lin F, Han YH, Dawson MI, Zhang XK. Mitogenic effect of orphan receptor TR3 and its regulation by MEKK1 in lung cancer cells. Mol Cell Biol 2003; 23:8651-67.

50. Suzuki S, Suzuki N, Mirtsos C, Horacek T, Lye E, Noh SK, Ho A, Bouchard D, Mak TW, Yeh WC. Nur77 as a survival factor in tumor necrosis factor signaling. Proc Natl Acad Sci USA $2003 ; 100: 8276-80$.

51. Maruyama K, Tsukada T, Ohkura N, Bandoh S, Hosono T, Yamaguchi K. The NGFI-B subfamily of the nuclear receptor superfamily (review). Int J Oncol 1998; 12:1237-43.

52. Zamzami N, Kroemer G. The mitochondrion in apoptosis: How Pandora's box opens. Nat Rev Mol Cell Biol 2001; 2:67-71.

53. Li H, Kolluri SK, Gu J, Dawson MI, Cao X, Hobbs PD, Lin B, Chen G, Lu J, Lin F, Xie Z, Fontana JA, Reed JC, Zhang X. Cytochrome c release and apoptosis induced by mitochondrial targeting of nuclear orphan receptor TR3. Science 2000; 289:1159-64.

54. Li Y, Lin B, Agadir A, Liu R, Dawson MI, Reed JC, Fontana JA, Bost F, Hobbs PD, Zheng Y, Chen GQ, Shroot B, Mercola D, Zhang XK. Molecular determinants of AHPN (CD437)-induced growth arrest and apoptosis in human lung cancer cell lines. Mol Cell Biol 1998; 18:4719-31.

55. Weih F, Ryseck RP, Chen L, Bravo R. Apoptosis of nur77/N10-transgenic thymocytes involves the Fas/Fas ligand pathway. Proc Natl Acad Sci USA 1996; 93:5533-8.

56. Zetterstrom RH, Solomin L, Jansson L, Hoffer BJ, Olson L, Perlmann T. Dopamine neuron agenesis in Nurr1-deficient mice. Science 1997; 276:248-50.

57. Rajpal A, Cho YA, Yelent B, Koza-Taylor PH, Li D, Chen E, Whang M, Kang C, Turi TG, Winoto A. Transcriptional activation of known and novel apoptotic pathways by Nur77 orphan steroid receptor. EMBO J 2003; 22:6526-36.

58. Maira M, Martens C, Philips A, Drouin J. Heterodimerization between members of the Nur subfamily of orphan nuclear receptors as a novel mechanism for gene activation. Mol Cell Biol 1999; 19:7549-57.

59. Philips A, Lesage S, Gingras R, Maira MH, Gauthier Y, Hugo P, Drouin J. Novel dimeric Nur77 signaling mechanism in endocrine and lymphoid cells. Mol Cell Biol 1997; 17:5946-51.
60. Perlmann T, Jansson L. A novel pathway for vitamin A signaling mediated by RXR heterodimerization with NGFI-B and NURR1. Genes Dev 1995; 9:769-82.

61. Wallen-Mackenzie A, Mata de Urquiza A, Petersson S, Rodriguez FJ, Friling S, Wagner J, Ordentlich P, Lengqvist J, Heyman RA, Arenas E, Perlmann T. Nurr1-RXR heterodimers mediate RXR ligand-induced signaling in neuronal cells. Genes Dev 2003; 17:3036-47.

62. Zetterstrom RH, Solomin L, Mitsiadis T, Olson L, Perlmann T. Retinoid X receptor heterodimerization and developmental expression distinguish the orphan nuclear receptors NGFI-B, Nurr1, and Nor1. Mol Endocrinol 1996; 10:1656-66.

63. Wu Q, Li Y, Liu R, Agadir A, Lee MO, Liu Y, Zhang X. Modulation of retinoic acid sensitivity in lung cancer cells through dynamic balance of orphan receptors nur77 and COUP-TF and their heterodimerization. EMBO J 1997; 16:1656-69.

64. Masuyama N, Oishi K, Mori Y, Ueno T, Takahama Y, Gotoh Y. Akt inhibits the orphan nuclear receptor Nur77 and T-cell apoptosis. J Biol Chem 2001; 276:32799-805.

65. Pekarsky Y, Hallas C, Palamarchuk A, Koval A, Bullrich F, Hirata Y, Bichi R, Letofsky J, Croce CM. Akt phosphorylates and regulates the orphan nuclear receptor Nur77. Proc Natl Acad Sci USA 2001; 98:3690-4.

66. Cao X, Liu W, Lin F, Li H, Kolluri SK, Lin B, Han YH, Dawson MI, Zhang XK. Retinoid $\mathrm{X}$ receptor regulates Nur77/TR3-dependent apoptosis [corrected] by modulating its nuclear export and mitochondrial targeting. Mol Cell Biol 2004; 24:9705-25.

67. Uemura H, Chang C. Antisense TR3 orphan receptor can increase prostate cancer cell viability with etoposide treatment. Endocrinology 1998; 139:2329-34.

68. Ramaswamy S, Ross KN, Lander ES, Golub TR. A molecular signature of metastasis in primary solid tumors. Nat Genet 2003; 33:49-54.

69. Clark J, Benjamin H, Gill S, Sidhar S, Goodwin G, Crew J, Gusterson BA, Shipley J, Cooper CS. Fusion of the EWS gene to CHN, a member of the steroid/thyroid receptor gene superfamily, in a human myxoid chondrosarcoma. Oncogene 1996; 12:229-35.

70. Labelle Y, Bussieres J, Courjal F, Goldring MB. The EWS/TEC fusion protein encoded by the $\mathrm{t}(9 ; 22)$ chromosomal translocation in human chondrosarcomas is a highly potent transcriptional activator. Oncogene 1999; 18:3303-8

71. Freyer GA, Katoh Y, Roberts RJ. Characterization of the major mRNAs from adenovirus 2 early region 4 by cDNA cloning and sequencing. Nucleic Acids Res 1984; 12:3503-19.

72. Halbert DN, Cutt JR, Shenk T. Adenovirus early region 4 encodes functions required for efficient DNA replication, late gene expression, and host cell shutoff. J Virol 1985; 56:250-7.

73. Mitrus I, Missol-Kolka E, Plucienniczak A, Szala S. Tumour therapy with genes encoding apoptin and E4orf4. Anticancer Res 2005; 25:1087-90.

74. Branton PE, Roopchand DE. The role of adenovirus E4orf4 protein in viral replication and cell killing. Oncogene 2001; 20:7855-65.

75. Kleinberger T. Induction of apoptosis by adenovirus E4orf4 protein. Apoptosis 2000; 5:211-5.

76. Marcellus RC, Chan H, Paquette D, Thirlwell S, Boivin D, Branton PE. Induction of p53-independent apoptosis by the adenovirus E4orf4 protein requires binding to the Balpha subunit of protein phosphatase 2A. J Virol 2000; 74:7869-77.

77. Miron MJ, Gallouzi IE, Lavoie JN, Branton PE. Nuclear localization of the adenovirus E4orf4 protein is mediated through an arginine-rich motif and correlates with cell death. Oncogene 2004; 23:7458-68.

78. Marcellus RC, Lavoie JN, Boivin D, Shore GC, Ketner G, Branton PE. The early region 4 orf4 protein of human adenovirus type 5 induces $\mathrm{p} 53$-independent cell death by apoptosis. J Virol 1998; 72:7144-53.

79. Shtrichman R, Kleinberger T. Adenovirus type $5 \mathrm{E} 4$ open reading frame 4 protein induces apoptosis in transformed cells. J Virol 1998; 72:2975-82.

80. Shtrichman R, Sharf R, Barr H, Dobner T, Kleinberger T. Induction of apoptosis by adenovirus E4orf4 protein is specific to transformed cells and requires an interaction with protein phosphatase 2A. Proc Natl Acad Sci USA 1999; 96:10080-5.

81. Livne A, Shtrichman R, Kleinberger T. Caspase activation by adenovirus e4orf4 protein is cell line specific and is mediated by the death receptor pathway. J Virol 2001; 75:789-98.

82. Bondesson M, Ohman K, Manervik M, Fan S, Akusjarvi G. Adenovirus E4 open reading frame 4 protein autoregulates E4 transcription by inhibiting E1A transactivation of the E4 promoter. J Virol 1996; 70:3844-51.

83. Kleinberger T, Shenk T. Adenovirus E4orf4 protein binds to protein phosphatase 2A, and the complex downregulates E1A-enhanced junB transcription. J Virol 1993; 67:7556-60.

84. Lavoie JN, Nguyen M, Marcellus RC, Branton PE, Shore GC. E4orf4, a novel adenovirus death factor that induces $\mathrm{p} 53$-independent apoptosis by a pathway that is not inhibited by zVAD-fmk. J Cell Biol 1998; 140:637-45.

85. Van Hoof C, Goris J. Phosphatases in apoptosis: To be or not to be, PP2A is in the hear of the question. Biochim Biophys Acta 2003; 1640:97-104.

86. Shtrichman R, Sharf R, Kleinberger T. Adenovirus E4orf4 protein interacts with both Balpha and B' subunits of protein phosphatase 2A, but E4orf4-induced apoptosis is mediated only by the interaction with Balpha. Oncogene 2000; 19:3757-65.

87. Mannervik M, Fan S, Strom AC, Helin K, Akusjarvi G. Adenovirus E4 open reading frame 4-induced dephosphorylation inhibits E1A activation of the E2 promoter and E2F-1-mediated transactivation independently of the retinoblastoma tumor suppressor protein. Virology 1999; 256:313-21.

88. Muller U, Kleinberger T, Shenk T. Adenovirus E4orf4 protein reduces phosphorylation of c-Fos and E1A proteins while simultaneously reducing the level of AP-1. J Virol 1992; 66:5867-78.

89. Whalen SG, Marcellus RC, Whalen A, Ahn NG, Ricciardi RP, Branton PE. Phosphorylation within the transactivation domain of adenovirus E1A protein by mitogen-activated protein kinase regulates expression of early region 4. J Virol 1997; 71:3545-53. 
90. Estmer-Nilsson C, Petersen-Mahrt S, Durot C, Shtrichman R, Krainer AR, Kleinberger T, Akusjarvi G. The adenovirus E4-ORF4 splicing enhancer protein interacts with a subset of phosphorylated SR proteins. EMBO J 2001; 20:864-71.

91. Kanopka A, Muhlemann O, Petersen-Mahrt S, Estmer C, Ohrmalm C, Akusjarvi G. Regulation of adenovirus alternative RNA splicing by dephosphorylation of SR proteins. Nature 1998; 393:185-7.

92. Afifi R, Sharf R, Shtrichman R, Kleinberger T. Selection of apoptosis-deficient adenovirus E4orf4 mutants in Saccharomyces cerevisiae. J Virol 2001; 75:4444-7.

93. Kornitzer D, Sharf R, Kleinberger T. Adenovirus E4orf4 protein induces PP2A-dependent growth arrest in Saccharomyces cerevisiae and interacts with the anaphase-promoting complex/cyclosome. J Cell Biol 2001; 154:331-44.

94. Roopchand DE, Lee JM, Shahinian S, Paquette D, Bussey H, Branton PE. Toxicity of human adenovirus E4orf4 protein in Saccharomyces cerevisiae results from interactions with the Cdc55 regulatory B subunit of PP2A. Oncogene 2001; 20:5279-90.

95. Gingras MC, Champagne C, Roy M, Lavoie JN. Cytoplasmic death signal triggered by SRC-mediated phosphorylation of the adenovirus E4orf4 protein. Mol Cell Biol 2002; 22:41-56.

96. Lavoie JN, Champagne C, Gingras MC, Robert A. Adenovirus E4 open reading frame 4-induced apoptosis involves dysregulation of Src family kinases. J Cell Biol 2000; 150:1037-56.

97. Ossareh-Nazari B, Bachelerie F, Dargemont C. Evidence for a role of CRM1 in signal-mediated nuclear protein export. Science 1997; 278:141-4.

98. Robert A, Miron MJ, Champagne C, Gingras MC, Branton PE, Lavoie JN. Distinct cell death pathways triggered by the adenovirus early region 4 ORF 4 protein. J Cell Biol 2002; 158:519-28.

99. Champagne C, Landry MC, Gingras MC, Lavoie JN. Activation of adenovirus type 2 early region 4 ORF4 cytoplasmic death function by direct binding to Src kinase domain. J Biol Chem 2004; 279:25905-15.

100. O'Shea C, Klupsch K, Choi S, Bagus B, Soria C, Shen J, McCormick F, Stokoe D. Adenoviral proteins mimic nutrient/growth signals to activate the mTOR pathway for viral replication. EMBO J 2005; 24:1211-21.

101. O'Shea CC, Choi S, McCormick F, Stokoe D. Adenovirus overrides cellular checkpoints for protein translation. Cell Cycle 2005; 4:883-8.

102. Kroczak TJ, Baran J, Pryjma JSM, Reshedi I, Hernandez E, Alberti E, Maddika S, Los M. The emerging importance of DNA mapping and other comprehensive screening techniques as tools to identify new drug targets and as a mean of (cancer) therapy personalization. Expert Opin Ther Targets 2006; In press.

103. Philchenkov A, Zavelevich M, Kroczak TJ, Los M. Caspases and cancer: Mechanisms of inactivation and new treatment modalities. Exp Oncol 2004; 26:82-97.

104. Johar D, Roth JC, Bay GH, Walker JN, Kroczak TJ, Los M. Inflammatory response, reactive oxygen species, programmed (necrotic-like and apoptotic) cell death and cancer. Rocz Akad Med Bialymst 2004; 49:31-9.

105. Plautz GE, Cohen PA, Shu S. Considerations on clinical use of T cell immunotherapy for cancer. Arch Immunol Ther Exp 2003; 51:245-57.

106. Ghavami S, Kerkhoff C, Los M, Hashemi M, Sorg C, Karami-Tehrani F. Mechanism of apoptosis induced by S100A8/A9 in colon cancer cell lines: The role of ROS and the effect of metal ions. J Leukoc Biol 2004; 76:169-75.

107. Chlichlia K, Schirrmacher V, Sandaltzopoulos R. Cancer immunotherapy: Battling tumors with gene vaccines. Curr Med Chem-Anti-Inflammatory and Anti-Allergy Agents 2005; 4:353-66.

108. Booy EP, Kadkhoda K, Johar D, Bay GH, Los M. The immune system, involvement in neurodegenerative diseases, ageing and cancer. Curr Med Chem-Anti-Inflammatory and Anti-Allergy Agents 2005; 4:349-53.

109. Barczyk K, Kreuter M, Pryjma J, Booy EP, Maddika S, Ghavami S, Berdel WE, Roth J, Los M. Serum cytochrome $\mathrm{c}$ indicates in vivo-apoptosis and it can serve as a prognostic marker during cancer therapy. Int J Cancer 2005; 114:167-73.

110. Renz A, Berdel WE, Kreuter M, Belka C, Schulze-Osthoff K, Los M. Rapid extracellular release of cytochrome $\mathrm{c}$ is specific for apoptosis and marks cell death in vivo. Blood 2001; 98:1542-8.

111. Hauff K, Zamzow C, Law WJ, de Melo J, Kennedy K, Los M. Peptide-based approaches to treat asthma, arthritis, other autoimmune diseases and pathologies of the central nervous system. Arch Immunol Ther Exp 2005; 53:308-20.

112. Kreuter M, Langer C, Kerkhoff C, Reddanna P, Kania AL, Maddika S, Chlichlia K, Bui TN, Los M. Stroke, myocardial infarction, acute and chronic inflammatory diseases: Caspases and other apoptotic molecules as targets for drug development. Arch Immunol Ther Exp 2004; 52:141-55.

113. Mendoza FJ, Espino P, Cann CL, Bristow N, McCrea K, Los M. Anti-tumor chemotherapy utilizing peptide-based approaches - Apoptotic pathways, kinases and proteasome as targets. Arch Immunol Ther Exp 2005; 53:47-60.

114. Standiford DM, Richter JD. Analysis of a developmentally regulated nuclear localization signal in Xenopus. J Cell Biol 1992; 118:991-1002.

115. Zhang F, White RL, Neufeld KL. Cell density and phosphorylation control the subcellular localization of adenomatous polyposis coli protein. Mol Cell Biol 2001; 21:8143-56.

116. Young DB, Jonnalagadda J, Gatei M, Jans DA, Meyn S, Khanna KK. Identification of domains of ataxia-telangiectasia mutated required for nuclear localization and chromatin association. J Biol Chem 2005; 280:27587-94.

117. Briggs LJ, Stein D, Goltz J, Corrigan VC, Efthymiadis A, Hubner S, Jans DA. The cAMP-dependent protein kinase site (Ser312) enhances dorsal nuclear import through facilitating nuclear localization sequence/importin interaction. J Biol Chem 1998; 273:22745-52.
118. Drier EA, Huang LH, Steward R. Nuclear import of the Drosophila Rel protein Dorsal is regulated by phosphorylation. Genes Dev 1999; 13:556-68.

119. Zhao X, Gan L, Pan H, Kan D, Majeski M, Adam SA, Unterman TG. Multiple elements regulate nuclear/cytoplasmic shuttling of FOXO1: Characterization of phosphorylationand 14-3-3-dependent and -independent mechanisms. Biochem J 2004; 378:839-49.

120. Chan CK, Jans DA. Synergy of importin alpha recognition and DNA binding by the yeast transcriptional activator GAL4. FEBS Lett 1999; 462:221-4.

121. Fineberg K, Fineberg T, Graessmann A, Luedtke NW, Tor Y, Lixin R, Jans DA, Loyter A. Inhibition of nuclear import mediated by the Rev-arginine rich motif by RNA molecules. Biochemistry 2003; 42:2625-33.

122. Hennekes H, Peter M, Weber K, Nigg EA. Phosphorylation on protein kinase C sites inhibits nuclear import of lamin B2. J Cell Biol 1993; 120:1293-304.

123. Beals CR, Clipstone NA, Ho SN, Crabtree GR. Nuclear localization of NF-ATc by a calcineurin-dependent, cyclosporin-sensitive intramolecular interaction. Genes Dev 1997; 11:824-34.

124. Traenckner EB, Wilk S, Baeuerle PA. A proteasome inhibitor prevents activation of NF-kappa B and stabilizes a newly phosphorylated form of I kappa B-alpha that is still bound to NF-kappa B. EMBO J 1994; 13:5433-41.

125. Saleh M, Huang H, Green NC, Featherstone MS. A conformational change in PBX1A is necessary for its nuclear localization. Exp Cell Res 2000; 260:105-15.

126. Kaffman A, Rank NM, O'Shea EK. Phosphorylation regulates association of the transcription factor Pho4 with its import receptor Pse1/Kap121. Genes Dev 1998; 12:2673-83.

127. Beg AA, Ruben SM, Scheinman RI, Haskill S, Rosen CA, Baldwin Jr AS. I kappa B interacts with the nuclear localization sequences of the subunits of NF-kappa B: A mechanism for cytoplasmic retention. Genes Dev 1992; 6:1899-913.

128. Hu W, Kemp BE, Jans DA. Kinetic properties of nuclear transport conferred by the retinoblastoma $(\mathrm{Rb})$ NLS. J Cell Biochem 2005; 95:782-93.

129. Hubner S, Xiao CY, Jans DA. The protein kinase CK2 site (Ser111/112) enhances recognition of the simian virus 40 large T-antigen nuclear localization sequence by importin. J Biol Chem 1997; 272:17191-5.

130. Jans DA, Jans P. Negative charge at the casein kinase II site flanking the nuclear localization signal of the SV40 large T-antigen is mechanistically important for enhanced nuclear import. Oncogene 1994; 9:2961-8.

131. Jans DA, Peters R, Jans P, Fahrenholz F. Vasopressin V2-receptor mobile fraction and ligand-dependent adenylate cyclase activity are directly correlated in LLC-PK1 renal epithelial cells. J Cell Biol 1991; 114:53-60.

132. Kalderon D, Richardson WD, Markham AF, Smith AE. Sequence requirements for nuclear location of simian virus 40 large-T antigen. Nature 1984; 311:33-8.

133. Xiao CY, Hubner S, Jans DA. SV4O large tumor antigen nuclear import is regulated by the double-stranded DNA-dependent protein kinase site (serine 120) flanking the nuclear localization sequence. J Biol Chem 1997; 272:22191-8.

134. Jans DA, Moll T, Nasmyth K, Jans P. Cyclin-dependent kinase site-regulated signal-dependent nuclear localization of the SW15 yeast transcription factor in mammalian cells. J Biol Chem 1995; 270:17064-7.

135. Harreman MT, Kline TM, Milford HG, Harben MB, Hodel AE, Corbett AH. Regulation of nuclear import by phosphorylation adjacent to nuclear localization signals. J Biol Chem 2004; 279:20613-21.

136. Forwood JK, Harley V, Jans DA. The C-terminal nuclear localization signal of the sex-determining region Y (SRY) high mobility group domain mediates nuclear import through importin beta 1. J Biol Chem 2001; 276:46575-82.

137. Thevenet L, Mejean C, Moniot B, Bonneaud N, Galeotti N, Aldrian-Herrada G, Poulat F, Berta P, Benkirane M, Boizet-Bonhoure B. Regulation of human SRY subcellular distribution by its acetylation/deacetylation. EMBO J 2004; 23:3336-45.

138. El-Hodiri HM, Che S, Nelman-Gonzalez M, Kuang J, Etkin LD. Mitogen-activated protein kinase and cyclin B/Cdc2 phosphorylate Xenopus nuclear factor 7 (xnf7) in extracts from mature oocytes. Implications for regulation of xnf7 subcellular localization. J Biol Chem 1997; 272:20463-70. 